Volume 1 Issue 1, March 2017: pp. 124-143. Copyright (c) 2017 HOLREV. Faculty of Law, Halu Oleo University, Kendari, Southeast Sulawesi, Indonesia. ISSN: 2548-1762 | e-ISSN: 2548-1754. Open Access at: http://ojs.uho.ac.id/index.php/holrev/

\title{
Aspek Hukum Badan Layanan Umum
}

\author{
Legal Aspect of Public Service Agency
}

\author{
Nasrullah Muhammadong \\ Dosen Fakultas Hukum Universitas Tadulako (Untad), Palu \\ E-mail: nasrullahmuhammadong@yahoo.com
}

\begin{abstract}
Public administration reform has been currently due crucial attention, particularly post-doctrinal concept of New Public Management (NPM) that refers to Reinventing Government. The NPM has formed a frame of managerial transformation or frame of governmental functional transformation. The Government has adopted the NPM's concept by implementing State Finance Reform that began in lately 2003. Several transformations have been run by the Government, that's called forerunner of the concept Public Service Agency [Badan Layanan Umum, (BLU)\}. BLU is a part of Government sale services that is formed in order to serve citizen in the form of provision of goods and/or services sold without prioritizing profit. In running for services, it based on principles of efficiency and productivity. BLU itself is actually operated by either central or local government. As for legal instrument, it has been regulated by Governmental Ordinance and Regulation of Minister for Internal Affairs. Besides explaining to legal aspect, this study also is not only exploring legal matters of BLU, but also analyzing some cases such implementing BLU on government hospital. Furthermore, it deeply goes to legal problem solving in which whether to necessarily form into Local Ordinance
\end{abstract}

Keyword: Legal Aspect; Public Service Agency; and Local Ordinance.

Abstrak: Reformasi administrasi publik makin gencar dilakukan dewasa ini, terutama pasca dikenalnya konsep Doktrin New Public Management (NPM) atau Reinventing Government. NPM merupakan pola transformasi manajemen atau pola transformasi fungsi pemerintahan. Negara Indonesia mengadopsi pemikiran NPM dengan melakukan reformasi keuangan negara yang mulai bergulir sejak akhir tahun 2003. Transformasi beberapa kegiatan pemerintah, itulah cikal bakal lahirnya konsep Badan Layanan Umum (BLU). BLU adalah instansi di lingkungan Pemerintah yang dibentuk untuk memberikan pelayanan kepada masyarakat berupa penyediaan barang dan/atau jasa yang dijual tanpa mengutamakan mencari keuntungan. Dalam melakukan kegiatannya didasarkan pada prinsip efisiensi dan produktivitas. BLU ada di tingkat Pusat, ada pula di tingkat daerah. Adapun instrumen hukum yang mengatur soal BLU, ada berupa Undang-Undang, Peraturan Pemerintah, dan Peraturan Menteri Dalam Negeri. Tulisan ini, di samping mengulas soal aspek hukum BLU, juga diberikan contoh kasus BLU, yaitu penerapan BLU pada 
rumah sakit milik pemerintah. Selanjutnya, analisis lebih menukik lagi pada pemecahan masalah, yakni perlu-tidaknya BLU dibuatkan lagi dalam bentuk Peraturan Daerah.

Kata kunci: Aspek Hukum; Badan Layanan Umum; Perda tentang Badan Layanan Umum.

\section{PENDAHULUAN}

Terdapat persepsi selama ini bahwa pemerintah dinilai menjadi sebagai organisasi yang birokratis yang tidak efisien, lambat dan tidak efektif. Padahal dalam manajemen modern unit pemerintahan harus profesional dan transparan.

Namun dewasa ini, reformasi administrasi publik pun makin gencar dilakukan, terutama pasca dikenalnya konsep Doktrin New Public Management (NPM) atau Reinventing Government. Didasarkan kepada pengalaman negara-negara Eropa, Amerika Serikat, Australia, dan Selandia Baru, NPM atau Reinventing Government secara berangsurangsur diadopsi ke dalam manajemen pemerintahan di berbagai negara, termasuk Indonesia.

Dalam doktrin NPM, pemerintah dianjurkan untuk meninggalkan paradigma administrasi tradisional yang cenderung mengutamakan sistem dan prosedur birokratis yang tidak efisien, pemberian layanan yang lambat/tidak efektif, dan menggantikannya dengan orientasi pada kinerja dan hasil. Dengan kata lain, pemerintah dianjurkan untuk melepaskan diri dari birokrasi klasik, kemudian mendorong organisasi dan pegawai agar lebih fleksibel, menetapkan tujuan, serta menentukan target organisasi lebih jelas, yang pada akhirnya dapat memungkinkan pengukuran hasil. ${ }^{1}$ Alhasil, transformasi manajemen pemerintahan dalam NPM meliputi penataan kelembagaan (Institutional Arrangement), reformasi kepegawaian (Civil Servant Reform), dan reformasi pengelolaan keuangan Negara (New Management Reform). ${ }^{2}$

Negara Indonesia mengadopsi pemikiran NPM dengan melakukan reformasi keuangan negara yang mulai bergulir sejak akhir tahun 2003, dengan dikeluarkannya tiga paket peraturan keuangan negara yang baru, yaitu 1) Undang-Undang Nomor 17 Tahun 2003 tentang Keuangan Negara; 2) Undang-Undang Nomor 1 Tahun 2004 tentang

1 Agus Dwiyanto, dkk., Reformasi Tata Pemerintahan dan Otonomi Daerah, Yogyakarta: PSKK-UGM, 2003, hal 43.

2 Mahmudi, New Public Management (NPM): Pendekatan Baru Manajemen Sektor Publik, 2003, http://journal.vii.ac. id/index.php/ sinerji/artikel. 
Perbendaharaan Negara, dan 3) Undang-Undang Nomor 15 Tahun 2005 tentang Pemeriksaan Keuangan Negara.

Ketiga paket peraturan keuangan negara tersebut di atas, telah merubah pola pikir atas pelayanan birokrasi agar lebih efisien, profesionalitas, akuntabel, dan transparan. Perubahan pola pikir dimaksud, juga telah mengubah managemen penganggaran tradisional menjadi penganggaran berbasis kinerja. Dengan basis kinerja ini, arah penggunaan dana pemerintah menjadi lebih jelas, dari hanya membiayai input dan proses, menjadi berorientasi pada output. Perubahan ini sangat berarti mengingat kebutuhan dana yang semakin tinggi, sedangkan sumber daya yang dimiliki pemerintah terbatas. ${ }^{3}$

Sebagaimana disinggung tadi, NPM merupakan pola transformasi manajemen atau pola transformasi fungsi pemerintahan. Menyangkut transformasi fungsi pemerintahan, menurut Joko Supriyanto dan Suparjo dapat dilakukan dengan tiga cara, yaitu rightsizing (cut the government), corporatization dan privatization. Namun menurut mereka, tidak semua kegiatan pemerintah bisa ditransformasikan sebagai unit yang otonom dengan pola di atas. Transformasi fungsi kegiatan sebagai unit yang otonom dapat dilakukan pada berbagai kegiatan, antara lain: kegiatan pelayanan pendidikan, kesehatan masyarakat, administrasi kependudukan, pembibitan dan pembenihan, pengolahan data, administrasi kendaraan, pengelolaan dana bergulir, pembinaan olahraga, pemeliharaan jalan, pemungutan pajak dan retribusi, pembinaan calon tenaga kerja, pertamanan dan kebersihan. Jadi, berbagai kegiatan pemerintah bisa ditransformasikan sebagaimana yang dijelaskan tadi, maka itulah sebagai cikal bakal lahirnya konsep apa yang disebut dengan Badan Layanan Umum. ${ }^{4}$

3 M. Irfan Islamy, Reformasi Pelayanan Umum, Makalah Pelatihan Strategi Pembangunan Sumber Manusia Aparatur Pemerintah Daerah dalam Era Globalisasi, di Kabupaten Daerah Tingkat II Trenggalek, 1999, hal. 37.

4 Joko Supriyanto dan Suparjo, Disarikan dari Acara Workshop Penyusunan RPP tentang Pengelolaan Keuangan Badan Layanan Umum (BLU). Sumber: www.perbendaharaan.go.id. Menurut Joko Supriyanto dan Suparjo, kegiatan yang tidak bisa ditranformasikan sebagai unit yang otonom antara lain: kegiatan legislasi, pengaturan (regulasi), penetapan kebijakan pelayanan, penganggaran, peradilan, penindakan, dan pertanggungjawaban. 


\section{ANALISIS DAN PEMBAHASAN}

\section{Pengertian Badan Layanan Umum (BLU) dan Karakteristiknya ${ }^{5}$}

Pengertian Badan Layanan Umum (selanjutnya disingkat BLU) ${ }^{6}$, diatur dalam Pasal 1 angka 23 Undang-Undang Nomor 1 Tahun 2004 tentang Perbendaharaan Negara, yaitu: “Badan Layanan Umum adalah instansi di lingkungan Pemerintah yang dibentuk untuk memberikan pelayanan kepada masyarakat berupa penyediaan barang dan/atau jasa yang dijual tanpa mengutamakan mencari keuntungan dan dalam melakukan kegiatannya didasarkan pada prinsip efisiensi dan produktivitas".

Pengertian di atas diadopsi kembali dalam peraturan pelaksanaannya yaitu dalam Pasal 1 angka 1 Peraturan Pemerintah Nomor 23 Tahun 2005 tentang Pengelolaan Keuangan Badan Layanan Umum. Badan Layanan Umum adalah suatu badan usaha pemerintah yang tidak bertujuan mencari laba, meningkatkan kualitas pelayanan publik, dan memberikan otonomi atau fleksibilitas manajemen instansi/lembaga, baik milik pemerintah pusat maupun pemerintah daerah.

BLU memiliki karakteristik tertentu yang membedakannya dengan instansi pemerintah lainnya, yaitu: ${ }^{7}$

1. Berkedudukan sebagai lembaga pemerintah yang tidak dipisahkan dari kekayaan negara.

2. Menghasilkan barang dan/atau jasa yang diperlukan masyarakat.

3. Tidak bertujuan untuk mencari laba.

4. Dikelola secara otonom dengan prinsip efisiensi dan produktivitas ala korporasi.

5. Rencana kerja, anggaran, dan pertanggungjawabannya dikonsolidasikan pada instansi induk.

6. Penerimaan baik pendapatan maupun sumbangan dapat digunakan secara langsung.

7. Pegawai dapat terdiri dari pegawai negeri sipil dan bukan pegawai negeri sipil.

5 Istilah pelayanan umum disebut juga dengan istilah pelayanan kepada orang banyak (masyarakat), pelayanan sosial, pelayanan umum dan pelayanan prima. Menurut Moenir, pelayanan umum adalah kegiatan yang dilakukan oleh seseorang atau sekelompok orang dengan landasan faktor material melalui sistem, prosedur dan metode tertentu dalam rangka usaha memenuhi kepentingan orang lain sesuai haknya. (lihat Moenir, H.A.S., Pendekatan Manusiawi Dan Organisasi Terhadap Pembinaan Kepegawaian, Gunung Agung, Jakarta, 1998, hal. 26.

6 "BLU", merupakan singkatan, yang juga digunakan dalam PP No 23 Tahun 2005.

7 Sie Infokum-Ditama Binbangkum, 2009, Badan Layanan Umum, http//:www.jdih.bpk.go.id. 
8. BLU bukan subyek pajak.

Bentuk keistimewaan lain BLU, khususnya dalam fleksibilitas pengelolaan keuangan, yaitu: ${ }^{8}$

1. Pendapatan operasional dapat digunakan langsung sesuai Rencana Bisnis dan Anggaran (RBA) tanpa terlebih dahulu disetorkan ke rekening kas negara atau daerah. Namun seluruh pendapatan tersebut, merupakan PNBP yang wajib dilaporkan dalam Laporan Realisasi Anggaran.

2. Anggaran belanja BLU merupakan anggaran fleksibel berdasarkan kesetaraan antara volume kegiatan pelayanan dengan jumlah pengeluaran.

3. Dalam rangka pengelolaan kas, BLU dapat merencanakan penerimaan dan pengeluaran kas, melakukan pemungutan/tagihan, menyimpan kas dan mengelola rekening bank, melakukan pembayaran, dan mendapatkan sumber dana untuk menutup defisit jangka pendek.

4. BLU dapat mengelola piutang dan utang sepanjang dikelola dan diselesaikan secara tertib, efisien, ekonomis, dan transparan, serta memberikan nilai tambah sesuai praktik bisnis yang sehat.

5. BLU dapat melakukan investasi jangka pendek maupun jangka panjang.

6. Pengadaan barang dan jasa BLU yang sumber dananya berasal dari pendapatan operasional, hibah tidak terikat, hasil kerjasama dengan pihak lainnya, dapat dilaksanakan berdasarkan ketentuan pengadaan barang/jasa yang ditetapkan oleh pimpinan BLU.

7. BLU dapat mengembangkan kebijakan, sistem, dan prosedur pengelolaan keuangan.

8. BLU dapat memperkerjakan tenaga profesional non PNS.

9. Pejabat pengelola, dewan pengawas dan pegawai dapat diberikan remunerasi berdasarkan tingkat tanggung-jawab dan tuntutan profesionalisme.

\section{Badan Layanan Umum Daerah (BLUD)}

Sebelumnya perlu diketahui, BLU dapat dibentuk di Pusat, . Misalnya di lingkungan departemen. Departemen Pendidikan Nasional ada BLU perguruan tinggi negeri.

8 Direktorat Pembinaan PK BLU Direktorat Jenderal Perbendaharaan Departemen Keuangan RI, Modul Bimbingan Teknis Penyusunan Persyaratan Adminstratif untuk Menerapkan PPK-BLU, 2008, hal 47. 
Departemen Pertanian ada BLU yang memproduksi semen, obat-obatan, dan susu. Di Departemen Kehutanan ada BLU yang memproduksi olahan hasil hutan, dan seterusnya. Adapun BLU yang dibentuk di tingkat daerah, itulah yang dikenal dengan nama "Badan Layanan Umum Daerah", (selanjutnya disingkat BLUD). ${ }^{9}$

Peraturan Menteri Dalam Negeri (Permendagri) Nomor 61 Tahun 2007 tentang Pedoman Teknis Pengelolaan Keuangan Badan Layanan Umum Daerah, memberikan definisi tentang Badan Layanan Umum Daerah. Yang dimaksud dengan Badan Layanan Umum Daerah adalah Satuan Kerja Perangkat Daerah atau Unit Kerja pada Satuan Kerja Perangkat Daerah di lingkungan pemerintah daerah yang dibentuk untuk memberikan pelayanan kepada masyarakat berupa penyediaan barang dan/atau jasa yang dijual tanpa mengutamakan mencari keuntungan dan dalam melakukan kegiatannya didasarkan pada prinsip efisiensi dan produktivitas.

BLUD merupakan bagian dari perangkat pemerintah daerah, dengan status hukum tidak terpisah dari pemerintah daerah. Berbeda dengan SKPD pada umumnya, pola pengelolaan keuangan BLUD memberikan fleksibilitas berupa keleluasaan untuk menerapkan praktik-praktik bisnis yang sehat untuk meningkatkan pelayanan kepada masyarakat, seperti pengecualian dari ketentuan pengelolaan keuangan daerah pada umumnya. Mengapa BLUD sangat diperlukan? Pertama, dapat dilakukan peningkatan pelayanan instansi pemerintah daerah kepada masyarakat dalam rangka memajukan kesejahteraan umum dan mencerdaskan kehidupan masyarakat; Kedua, instansi pemerintah daerah dapat memperoleh fleksibilitas dalam pengelolaan keuangan berdasarkan prinsip ekonomi dan produktivitas dengan menerapkan praktik bisnis yang sehat; dan ketiga, dapat dilakukan pengamanan atas aset daerah yang dikelola oleh instansi terkait.

Jadi sekali lagi, BLUD merupakan peluang yang secara khusus diberikan pada satuan kerja pemerintah daerah, yang memang khusus melaksanakan tugas pelayanan umum. Dalam makna lain, bahwa ada upaya peng-agenan aktivitas yang diberikan kepada instansi atau satuan pemerintah daerah dengan menerapkan pola keuangan ala bisnis, yang tentu target ingin dicapai adalah pemberian pelayanan kepada masyarakat lebih efisien dan efektif.

9 “BLUD” merupakan singkatan, yang juga digunakan dalam Permendagri Nomor 61 Tahun 2007. 


\section{Berbagai Instrumen Hukum Yang Mengatur tentang BLU}

\section{Undang-Undang Nomor 1 Tahun 2004 tentang Perbendaharaan Negara. 10}

Dalam Pasal 1 angka 23 Undang-Undang Nomor 1 Tahun 2004, dijelaskan pengertian BLU: "Badan Layanan Umum adalah instansi di lingkungan Pemerintah yang dibentuk untuk memberikan pelayanan kepada masyarakat berupa penyediaan barang dan/atau jasa yang dijual tanpa mengutamakan mencari keuntungan dan dalam melakukan kegiatannya didasarkan pada prinsip efisiensi dan produktivitas".

Pasal 68 menerangkan, BLU dibentuk untuk meningkatkan pelayanan kepada masyarakat dalam rangka memajukan kesejahteraan umum dan mencerdaskan kehidupan bangsa. Menyangkut kekayaan BLU, dijelaskan pula, yaitu merupakan kekayaan negara atau daerah yang tidak dipisahkan serta dikelola dan dimanfaatkan sepenuhnya untuk menyelenggarakan kegiatan BLU. Soal pembinaan keuangan BLU di tingkat pusat, juga dijelaskan, yaitu dilakukan oleh Menteri Keuangan dan pembinaan teknis dilakukan oleh menteri yang bertanggung jawab atas bidang pemerintahan yang bersangkutan. Adapun untuk pembinaan keuangan BLU yang ada di daerah, dilakukan oleh pejabat pengelola keuangan daerah. Adapun pembinaan teknis dilakukan oleh kepala satuan kerja perangkat daerah yang bertanggung jawab atas bidang pemerintahan yang bersangkutan.

\section{PP Nomor 23 Tahun 2005 tentang Pengelolaan Keuangan Badan Layanan Umum. ${ }^{11}$}

Diterbitkannya Peraturan Pemerintah (PP) Nomor 23 Tahun 2005 tentang Pengelolaan Keuangan Badan Layanan Umum ini, adalah amanat dari Pasal 69 ayat (7) Undang-Undang Nomor 1 Tahun 2004 tentang Perbendaharaan Negara. PP tersebut bertujuan untuk meningkatkan pelayanan publik oleh Pemerintah, karena sebelumnya tidak ada pengaturan yang spesifik mengenai unit pemerintahan yang melakukan pelayanan kepada masyarakat. Kalaupun ada, modelnya juga beraneka ragam ketika itu. Jenis BLU di sini antara lain rumah sakit, lembaga pendidikan, pelayanan lisensi, penyiaran, dan lain-lain. ${ }^{12}$

Pasal 1 ayat (1) PP Nomor 23 Tahun 2005 ini, menyatakan: "Pola Pengelolaan Keuangan Badan Layanan Umum (atau disingkat PPK-BLU, pen), adalah pengelolaan

\footnotetext{
10 Dalam UU No 1 Tahun 2004 ini, dapat dibaca pengertian tentang BLU, dan gambaran umum tentang pengelolaan keuangan BLU.

11 Dalam PP No 23 Tahun 2005 ini, dapat dibaca pengertian PPK-BLUD, serta asas dan persyaratan untuk memperoleh status BLU.

12 Tjandra Aditama, Manajemen Administrasi Rumah Sakit.Jakarta: UI Press, 2007, hal 67
} 
keuangan yang memberikan fleksibilitas berupa keleluasaan untuk menerapkan praktikpraktik bisnis yang sehat untuk meningkatkan pelayanan kepada masyarakat, dalam rangka memajukan kesejahteraan dan mencerdaskan kehidupan bangsa, sebagai pengecualian dari ketentuan pengelolaan keuangan negara pada umumnya".

Adapun tujuan BLU, yaitu, untuk meningkatkan pelayanan kepada masyarakat dalam rangka memajukan kesejahteraan umum dan mencerdaskan kehidupan bangsa dengan memberikan fleksibilitas dalam pengelolaan keuangan berdasarkan prinsip ekonomi dan produktivitas dan penerapan praktik bisnis yang sehat" (Pasal 68 ayat [1]). Tentu yang dimaksud dengan praktik bisnis yang sehat adalah, penyelenggaraan fungsi organisasi berdasarkan kaidah-kaidah manajemen yang baik dalam rangka pemberian layanan yang bermutu serta manajemen yang berkesinambungan.

Untuk asas pengelolaan BLU (Pasal 3):

1. Menyelenggarakan pelayanan umum yang pengelolaannya berdasarkan kewenangan yang didelegasikan, tidak terpisah secara hukum dari instansi induknya.

2. Pejabat BLU bertanggungjawab atas pelaksanaan kegiatan layanan umum kepada pimpinan instansi induk.

3. BLU tidak mencari laba.

4. Rencana kerja, anggaran dan laporan BLU dengan instansi induk tidak terpisah.

5. Pengelolaan sejalan dengan praktik bisnis yang sehat.

Bagaimana syarat untuk menjadi BLU? Yakni harus memenuhi (Pasal 4):

a. persyaratan substantif. Yaitu instansi pemerintah menyelenggarakan layanan umum, yang berhubungan dengan:

1. Penyediaan barang dan/atau jasa layanan umum;

2. Pengelolaan wilayah/kawasan tertentu untuk tujuan;

3. meningkatkan perekonomian masyarakat atau layanan umum; dan/atau

4. Pengelolaan dana khusus dalam rangka meningkatkan ekonomi dan/atau pelayanan kepada masyarakat.

b. persyaratan teknis, apabila:

1. kinerja pelayanan di bidang tugas pokok dan fungsinya layak dikelola dan ditingkatkan pencapaiannya melalui BLU sebagaimana direkomendasikan oleh menteri/pimpinan lembaga/kepala SKPD sesuai dengan kewenangannya; dan 
2. kinerja keuangan satuan kerja instansi yang bersangkutan adalah sehat sebagaimana ditunjukkan dalam dokumen usulan penetapan BLU.

c. persyaratan administratif, apabila instansi pemerintah yang bersangkutan dapat menyajikan seluruh dokumen berupa:

1. pernyataan kesanggupan untuk meningkatkan kinerja pelayanan, keuangan, dan manfaat bagi masyarakat;

2. pola tata kelola;

3. rencana strategis bisnis;

4. laporan keuangan pokok;

5. standar pelayanan minimum; dan

6. laporan audit terakhir atau pernyataan bersedia untuk diaudit secara independen.

Khusus untuk persyaratan substantif di atas, dalam penjelasan Pasal 4 ayat (2), disebutkan: Bidang layanan umum yang diselenggarakan oleh instansi dengan PPK-BLU meliputi kegiatan pemerintah yang bersifat operasional dalam menyelenggarakan pelayanan umum yang menghasilkan semi barang/jasa publik (quasipublic goods).

Selanjutnya dijelaskan, contoh instansi yang menyelenggarakan penyediaan barang dan/atau jasa layanan umum adalah pelayanan bidang kesehatan seperti rumah sakit pusat atau daerah ${ }^{13}$, penyelenggaraan pendidikan ${ }^{14}$, serta pelayanan jasa penelitian dan pengujian. Contoh instansi yang melaksanakan kegiatan pengelolaan wilayah atau kawasan secara otonom adalah otoritas dan Kawasan Pengembangan Ekonomi Terpadu (Kapet). Contoh instansi yang melaksanakan pengelolaan dana adalah pengelola dana bergulir untuk usaha kecil dan menengah, pengelola penerusan pinjaman, dan pengelola tabungan perumahan.

Berdasarkan penilaian atas berbagai persyaratan di atas, pemerintah dapat menentukan apakah suatu unit dapat ditetapkan sebagai BLU dengan status BLU Penuh atau Bertahap, atau sebaliknya ditolak.

Status BLU secara penuh diberikan apabila seluruh persyaratan, baik substantif teknis, administratif telah dipenuhi dengan memuaskan. Adapun Status BLU-Bertahap diberikan apabila persyaratan substantif dan teknis telah terpenuhi, namun persyaratan

13 Rumah Sakit Pemerintah Daerah (RSPD) Provinsi Sulawesi Tengah, yang kini telah menerapkan PPKBLU, dan mendapatkan status BLU Penuh, yaitu RS. Undata dan RS Madani

14 Universitas Tadulako telah dinyatakan resmi sebagai instansi pemerintah yang menerapkan PPK-BLU secara penuh, sebagaimana diberitakan Media Tadulako, edisi VII, Juli 2012. 
administratif belum terpenuhi secara memuaskan (Pasal 5). Sebaliknya, pencabutan BLU dilakukan apabila BLU yang bersangkutan sudah tidak memenuhi persyaratan substantif, teknis, dan/atau Administratif (Pasal 6).

\section{PP Nomor 58 Tahun 2005 tentang Pengelolaan Keuangan Daerah}

Tujuan pemerintah membentuk BLUD, dapat dibaca dalam Pasal 145 dan 146 Peraturan Pemerintah (PP) Nomor 58/2005 ini, yaitu, "untuk meningkatkan pelayanan kepada masyarakat dalam rangka memajukan kesejahteraan umum dan mencerdaskan kehidupan bangsa".

Menyadari mulia dan beratnya untuk mencapai tujuan tersebut, timbul pesimisme mengingat birokrasi pemerintahan terutama berkaitan dengan mekanisme pengelolaan keuangan di daerah. Untuk mengantisipasi pesimisme tersebut serta upaya pemerintah mewujudkan tujuan BLUD, melalui pasal 150 PP Nomor 58 Tahun 2005 diamanatkan bahwa: "Pedoman teknis pengelolaan. keuangan BLUD diatur lebih lanjut oleh Menteri Dalam Negeri setelah memperoleh pertimbangan Menteri Keuangan". ${ }^{15}$

Substansi pasal 150 tersebut dapat diinterpretasikan; betapa Pengelolaan Keuangan BLUD harus diciptakan sedemikian rupa (bebas dan bertanggung jawab) sehingga BLUD mampu mewujudkan kinerja yang berkualitas dibidang pelayanan umum di daerah. Bebas dan bertanggung jawab dalam pengelolaan keuangan BLUD, dimaksudkan bahwa BLUD diberikan fleksibilitas dalam pengelolaan keuangan dengan mengutamakan, produktivitas, efisiensi dan efektivitas sesuai dengan praktik bisnis yang sehat. Dengan demikian meskipun BLUD dikecualikan dalam pengelolaan keuangannya dari mekanisme keuangan daerah pada umumnya, tetapi harus mampu menciptakan kinerja bisnis yang efisien, dan tepat sasaran. ${ }^{16}$

\section{Permendagri Nomor 61 Tahun 2007, tentang Pedoman Teknis Pengelolaan Keuangan} Badan Layanan Umum Daerah ${ }^{17}$

Peraturan Menteri Dalam Negeri (Permendagri) Nomor 61 Tahun 2007 ini, merupakan instrumen hukum yang lebih menukik lagi, yaitu memberi landasan hukum sekaligus mengatur soal teknis BLU di tingkat daerah.

15 Ontot Murwato, Fleksibilitas Pengelolaan keuangan Badan Layanan Umum Dearah, Majalah Ekonomi \& Bisnis Vol. 11, Nomor 2, Juni 2007, hal. 88.

16 Loc., Cit., hal. 89.

17 Dalam Permendagri No 61 Tahun 2007 ini, dapat dibaca tentang pengertian, Prinsip Tata Kelola, Status kelembagaan, Sumber Pendapatan, hingga soal Pembinaan BLUD. 
Dalam Pasal 1 angka 1 Permendagri ini, memberikan rumusan: Badan Layanan Umum Daerah adalah Satuan Kerja Perangkat Daerah atau Unit Kerja pada Satuan Kerja Perangkat Daerah di lingkungan pemerintah daerah yang dibentuk untuk memberikan pelayanan kepada masyarakat berupa penyediaan barang dan/atau jasa yang dijual tanpa mengutamakan mencari keuntungan, dan dalam melakukan kegiatannya didasarkan pada prinsip efisiensi dan produktivitas.

Adapun Pendapatan BLUD, dapat bersumber dari (Pasal 60):

a. jasa layanan;

b. hibah;

c. hasil kerjasama dengan pihak lain;

d. APBD;

e. APBN; dan

f. lain-lain pendapatan BLUD yang sah.

BLUD juga dapat melakukan kerjasama dengan pihak lain. Kerja sama dimaksud, dilakukan berdasarkan prinsip efisiensi, efektivitas, ekonomis dan saling menguntungkan (Pasal 96).

Untuk pembentukan "dewan pengawas", dimungkinkan, asal memperhatikan kriteria, yakni BLUD yang telah memiliki realisasi nilai omset tahunan menurut laporan operasional atau nilai aset menurut neraca yang memenuhi syarat minimal. Adapun Dewan Pengawas dibentuk dengan keputusan kepala daerah atas usulan pemimpin BLUD (Pasal 43).

Soal pembinaan BLUD (Pasal 122):

(1) Pembinaan teknis BLUD-SKPD dilakukan oleh kepala daerah melalui sekretaris daerah.

(2) Pembinaan teknis BLUD-Unit Kerja dilakukan oleh kepala SKPD yang bertanggungjawab atas urusan pemerintahan yang bersangkutan.

(3) Pembinaan keuangan BLUD dilakukan oleh PPKD.

Dan terakhir, soal, evaluasi dan penilaian kerja. Pasal 127 menegaskan, Evaluasi dan penilaian kinerja BLUD dilakukan setiap tahun oleh kepala daerah dan/atau dewan pengawas terhadap aspek keuangan dan non keuangan. Evaluasi dan penilaian kinerja dimaksud, bertujuan untuk mengukur tingkat pencapaian hasil pengelolaan BLUD sebagaimana ditetapkan dalam renstra bisnis dan RBA. 


\section{Rumah Sakit Sebagai BLU (Contoh Kasus) \\ Pentingnya BLU Rumah Sakit}

Sebelum menjelaskan tentang pentingnya BLU Rumah Sakit, akan dipaparkan dulu, kronologis-yuridis, sehingga melahirkan gagasan untuk menjadikan rumah sakit sebagai BLUD.

Berdasarkan Undang-Undang Nomor 5 Tahun 1974 Rumah Sakit Umum Pemerintah (RSUP) adalah Unit Pelaksana Teknis (UPT). Sebagai konsekuensi dari asas dekonsentrasi, RSUP menjadi UPT dari Depkes. Sedangkan Rumah Sakit Pemerintah Daerah (RSPD) menjadi UPT dari Dinas Kesehatan Provinsi, kabupaten/kota, dan ini juga sebagai konsekuensi dari penerapan asas desentralisasi. Alhasil, khusus RSPD, campur tangan Pemda untuk terlibat pada seluruh manajemen rumah sakit sangatlah besar. Ini juga bisa dilihat dari segi pembiayaan. Yaitu, 20 persen dari Pemda, dan 80 persen subsidi pemerintah pusat.

Kemudian terjadi reformasi pertama RSUP pada tahun 1992 ketika keluar Kepres Nomor 38/1991 tentang Unit Swadana. Artinya RSUP mempunyai kewenangan untuk menggunakan penerimaan fungsionalnya secara langsung. Dengan kata lain, revenue dapat dikelola secara mandiri oleh RSUP, walaupun subsidi masih ada. Unit swadana memang bukan reformasi kelembagaan, tapi mulai nyata adanya hubungan antara kemandirian pengelolaan revenue ini dengan peningkatan kualitas.

Reformasi ini hanya berjalan lima tahun, dengan dikeluarkannya Undang-Undang Nomor 20/1997 tentang Penerimaan Negara Bukan Pajak (PNBP). Maka RSUP yang sudah terbiasa mengelola anggaran pendapatan fungsionalnya sebagai rumah sakit unit swadana, harus mengembalikan dana tersebut ke kas negara. Adapun RSPD tidak terkena Undang-Undang ini. Tetapi, dengan dikeluarkannya Undang-Undang Nomor 1/2004 tentang Perbendaraan Negara, mulai dibuat terobosan dengan dibentuknya Badan Layanan Umum (BLU). Jadi RSPD walau berbentuk Lembaga Teknis Daerah, namun sistem keuangannya adalah BLUD.

Mengapa BLU Rumah Sakit dibutuhkan? Pertama, sebagai gambaran awal, dapat kita baca tulisan Dedi Afandi, tentang Hak atas Kesehatan itu sendiri. Menurut beliau, Hak terhadap kesehatan bukanlah berarti hak agar setiap orang untuk menjadi sehat, atau pemerintah harus menyediakan sarana pelayanan kesehatan yang mahal di luar kesanggupan pemerintah. Tetapi lebih menuntut agar pemerintah dan pejabat publik dapat membuat berbagai kebijakan dan rencana kerja yang mengarah kepada tersedia dan 
terjangkaunya sarana pelayanan kesehatan untuk semua dalam kemungkinan waktu yang secepatnya. ${ }^{18}$ Kedua, menarik apa yang diulas oleh harian Republika, Selasa, 18 Oktober 2005, sbb: "Rumah sakit adalah ujung tombak pembangunan kesehatan masyarakat. Namun, tak sedikit keluhan selama ini diarahkan pada kualitas pelayanan rumah sakit yang dinilai masih rendah. Ini terutama rumah sakit daerah atau rumah sakit milik pemerintah. Penyebabnya klasik, yaitu masalah keterbatasan dana. Sehingga rumah sakit (RSUD dan rumah sakit milik pemerintah) tidak bisa mengembangkan mutu layanannya, baik karena peralatan medis yang terbatas maupun kemampuan sumber daya manusia (SDM) yang rendah".

Selanjutnya diulas: "Menyadari hal tersebut, pemerintah kemudian mengeluarkan Peraturan Pemerintah (PP) Nomor 23 tahun 2005 tentang Pedoman Pengelolaan Keuangan Badan Layanan Umum (PPK-BLU). Dengan PP ini, maka status rumah sakit kini berubah menjadi BLU.19 Menteri Kesehatan, Siti Fadilah Supari, ketika itu menyatakan, sebelum ditetapkan menjadi BLU, RS yang berstatus Perjan telah diberi kesempatan untuk melewati masa transisi selama enam bulan. Dalam masa tersebut, ada rumah sakit yang tenang-tenang saja. Namun, ada juga yang bergejolak, baik positif maupun negatif. Dengan manajemen BLU, kata Menkes, maka sebuah RS mempunyai keleluasaan dan kelonggaran yang lebih untuk mendayagunakan uang pendapatan. "Namun, pendapatan tersebut harus dikelola sebaik-baiknya untuk meningkatkan mutu pelayanan bagi semua pasien. Juga untuk meningkatkan kualitas SDM, mengendalikan tarif pelayanan, mengelola sarana, dan bukannya untuk menumpuk keuntungan," katanya.

Direktur Utama BLU RS Sanglah Denpasar, dr. I Gusti Lanang M Rudiartha MHA, kepada Republika, juga mengatakan, bahwa dengan status BLU, rakyat miskin tetap akan mendapatkan pelayanan kesehatan yang memadai. "Masyarakat miskin sangat terbuka

18 Dedi Afandi, "Hak atas kesehatan adalah hak asasi manusia", Makalah pada Seminar KOMNAS HAM-PWI Sumatera Selatan, Palembang, 16 Maret 2006, hal. 25.

19 Pasca lahirnya PP No 23 Tahun 2005, pemerintah (sesuai usulan Depkes kepada Presiden melalui surat No 173/Menkes/II/2005 tgl 3 Februari 2005), langsung menetapkan 13 rumah sakit yang status awalnya adalah perusahaan jawatan (Perjan), diubah menjadi BLU. Yaitu enam RS di Jakarta (RSCM, RS Fatmawati, RS Persahabatan, RS Jantung dan Pembuluh Darah Harapan Kita, RSAB Harapan Kita, RS Kanker Dharmais), dan masing-masing satu RS, yakni di Bandung (RS Dr Hasan Sadikin), di Semarang (RS Dr Kariadi), di Yogyakarta (RS Dr Sardjito), di Denpasar (RS Sanglah), di Makassar (RS Dr Wahidin Sudirohusodo), di Padang (RS Dr M Djamil), dan RS Dr Mohammad Hoesin di Palembang (Lihat, A. Djojosugito, Seluk Beluk Rumah Sakit Berbentuk Perusahaan Jawatan, Jurnal MARSI Vol.III, Nomor1, 2002, hal. 25). 
dengan adanya pembiayaan dari Askes miskin. Yang jelas, dengan status BLU maka sisi manajemen, pelayanan, dan sebagainya harus sudah jelas arahnya," ujarnya.

Beberapa alasan lain menjadikan RSPD memiliki status sebagai BLUD:

a. Jika RSPD harus terlibat dengan birokrasi yang rumit dalam penentuan tarif ( misalnya tarif layanan kesehatan yang memerlukan waktu panjang untuk mendapatkan pengesahan dari DPRD), maka RSPD tersebut ketika menjadi BLUD, cukup memberitahukan kepada DPRD tentang tarif yang telah dibuatnya.

b. RSPD diberikan kewenangan untuk mengelola sendiri penerimaan kas terutama yang bersumber dari aktivitas operasional, tanpa harus menyetorkan ke kas umum daerah.

c. Para pejabat RSPD baik yang berasal dari PNS atau non PNS akan mendapat honorarium yang ditentukan khusus oleh BLUD. Honorarium tersebut ditentukan sedemikian rupa sehingga proporsional dengan tingkat profesionalismenya. Yang pasti jumlah take home pay-nya akan lebih tinggi dari gaji PNS yang setara.

d. Untuk pencapaian efektivitas dan efisiensi, BLUD-RSPD dapat melakukan pengadaan barang seperti membeli obat bagi rumah sakit daerah, tanpa mengacu mekanisme pengadaan barang sebagaimana diatur oleh pemerintah. Dengan demikian maka pengadaan barang akan menjadi efisien, sekaligus efektif. $^{20}$

\section{Pendelegasian Dalam Bentuk Peraturan Kepala Daerah}

Permendagri Nomor 61 Tahun 2007 tentang Pedoman Teknis Pengelolaan Keuangan Badan Layanan Umum Daerah, mengatur dalam beberapa pasalnya, tentang perintah atau pendelegasian kepada kepala daerah agar dapat mengatur (lebih lanjut) soal BLUD dalam bentuk "peraturan kepala daerah". Pasal-pasal dimaksud, yaitu:

\section{Pasal 55}

Ayat (1) Untuk menjamin ketersediaan, keterjangkauan dan kualitas pelayanan umum yang diberikan oleh BLUD, kepala daerah menetapkan standar pelayanan minimal BLUD dengan peraturan kepala daerah.

20 Lihat Ontot Murwato, “Fleksibilitas Pengelolaan...”, Loc., Cit, hal. 91. 
2. Pasal 58

Ayat (3) Tarif layanan sebagaimana dimaksud pada ayat (1) dan ayat (2), ditetapkan dengan peraturan kepala daerah dan disampaikan kepada pimpinan DPRD.

3. Pasal 86

Ayat (2) Kewenangan penghapusan piutang sebagaimana dimaksud pada ayat (1), ditetapkan dengan peraturan kepala daerah, dengan memperhatikan ketentuan peraturan perundang-undangan.

4. Pasal 88

Ayat (2) Kewenangan perikatan pinjaman sebagaimana dimaksud pada ayat (1), diatur dengan peraturan kepala daerah.

5. Pasal 105

Pengadaan barang dan/atau jasa sebagaimana dimaksud dalam Pasal 101 ayat (1), diselenggarakan berdasarkan jenjang nilai yang diatur dalam peraturan kepala daerah.

6. Pasal 116

Ayat (4) BLUD mengembangkan dan menerapkan sistem akuntansi dengan berpedoman pada standar akuntansi yang berlaku untuk BLUD yang bersangkutan dan ditetapkan oleh kepala daerah dengan peraturan kepala daerah.

Untuk konteks Provinsi Sulawesi Tengah, ada beberapa peraturan kepala daerah (dalam hal ini peraturan gubernur Sulawesi Tengah), yang khusus mengatur tentang BLUD serta SKPD yang menerapkan BLUD dimaksud, yaitu:

1. Pergul Nomor 19 Tahun 2010 tentang Pedoman Pengelolaan Keuangan BLUD Provinsi Sulawesi Tengah;

2. Pergul Nomor 21 Tahun 2011 tentang Penatausahaan Pola Pengelolaan Keuangan BLUD;

3. Pergul Nomor 50 Tahun 2011 tentang Tarif Pelayanan Kesehatan Pada Rumah Sakit Umum Daerah Undata Provinsi Sulawesi Tengah;

4. Pergul Nomor 51 Tahun 2011 tentang Tarif Pelayanan Kesehatan Pada Rumah Sakit Daerah Madani Provinsi Sulawesi Tengah.

Dari berbagai Pergul di atas, yang dapat diamati:

1. Pergul tentang Pedoman Pengelolaan Keuangan BLUD Provinsi Sulawesi Tengah dan Pergul tentang Penatausahaan Pola Pengelolaan Keuangan BLUD, 
adalah Pergul yang substansinya bersifat umum, dan memang tidak diperintahkan oleh Permendagri Nomor 61 Tahun 2007 untuk dibuat.

2. Pergul tentang Tarif Pelayanan Kesehatan Pada Rumah Sakit Umum Daerah Undata Provinsi Sulawesi Tengah, dan Pergul tentang Tarif Pelayanan Kesehatan Pada Rumah Sakit Daerah Madani Provinsi Sulawesi Tengah, merupakan Pergul yang dibuat dalam rangka melaksanakan perintah langsung Permendagri Nomor 61 Tahun 2007.

\section{Perdebatan Perlu-Tidaknya Dibuat Perda}

Sub judul di atas dibuat, karena ada diskusi kecil yang khusus membahas tentang bentuk instrumen hukum yang didelegasikan oleh Permendagri Nomor 61 Tahun 2007 dimaksud. Yakni, ada pemikiran agar BLUD tidak perlu diatur dalam bentuk Perda, dengan alasan normatif, bahwa itu tidak diperintahkan oleh Permendagri Nomor 61 Tahun 2007. Perintah itu ada, namun bukan dalam bentuk Perda tapi pendelegasiannya dalam bentuk peraturan kepala daerah. ${ }^{21}$

Berdasarkan pendapat di atas,, hemat penulis, perlu di amati kembali isi Permendagri tersebut. Yaitu apa saja yang menjadi fokus pendelegasian, dan itu wajib dibuat dalam bentuk "peraturan kepala daerah". Ternyata, pendelegasian menurut Permendagri itu, hanya ditujukan kepada hal-hal yang bersifat spesifik dan teknis. Baik, di sini akan ikhtisarkan kembali isi dari Permendagri dimaksud, yaitu tentang apa saja yang didelegasikan kepada kepala daerah untuk mengaturnya dalam bentuk "peraturan kepala daerah" (sebagaimana yang telah ditulis secara lengkap di atas), yaitu:

1. Standar Pelayanan Minimal (Pasal 55 ayat 1 );

2. Tarif Layanan (Pasal 58 ayat 3);

3. Kewenangan Penghapusan Piutang (Pasal 86 ayat 2);

4. Kewenangan Perikatan Pinjaman (Pasal 88 ayat 2);

5. Pengadaan Barang dan/atau Jasa Berdasarkan Jenjang Nilai (Pasal 105);

6. Penerapan sistem akuntansi dengan berpedoman pada standar akuntansi yang berlaku (Pasal 116 ayat 4).

21 Pendapat yang muncul ketika penulis melakukan diskusi dengan Kabag Perundang-Undangan, dan Kepala Biro Hukum Kantor Gubernur, Prov. Sulteng, pada tgl 30 Oktober 2012. 
Jadi sungguh jelas, perintah dari Permendagri untuk mengaturnya dalam bentuk "peraturan kepala daerah", hanya fokus ditujukan kepada hal-hal yang tertentu saja, mulai dari soal: standar pelayanan, tarif, penghapusan piutang, perikatan pinjaman, pengadaan barang/jasa, dan terakhir soal penerapan sistem akuntansi.

Andaikan tetap dipertahankan argumentasi, bahwa Perda tentang BLUD tidak dimungkinkan oleh Permendagri dimaksud, maka kita sebenarnya harus juga konsisten, bahwa Pergul tentang Pedoman Pengelolaan Keuangan BLUD Provinsi Sulawesi Tengah; dan Pergul tentang Penatausahaan Pola Pengelolaan Keuangan BLUD, semua itu tidak memiliki landasan untuk dibuat. Mengapa? Karena materi muatan dari kedua Pergul itu, sama sekali tidak ada didelegasikan oleh Permendagri tadi. Tapi, kenyataannya, kedua bentuk Pergul yang tidak didelegasikan oleh Permendagri tersebut, justru dibuat oleh Pemerintah Prov. Sulteng.

Analisis lain dapat berikan. Para pihak yang tetap menolak bahwa BLUD tidak bisa dibuat dalam bentuk Perda (dengan alasan juga sebagaimana tersebut di atas), yaitu, kesannya mereka ingin melakukan sebuah penafsiran yang dalam ilmu hukum disebut $a$ contrario (yaitu penafsiran dengan cara mencari makna kebalikannya).

Hemat penulis, kalau penafsiran a contrario yang mau dipakai, kita harus hati-hati, jangan sampai keliru. Sebagai contoh: ada aturan yang mengatakan "dilarang merokok", bukan berarti menurut penafsiran a contrario, di situ diperbolehkan kencing. Atau contoh lain, "di wilayah ini bebas pengemis", bukan berarti preman dan gelandangan boleh berkeliaran di situ, dst. ${ }^{22}$ Begitu pula dalam kasus ini: Permendagri Nomor 61 Tahun 2007, hanya menyebut dalam bentuk "peraturan kepala daerah" (itu pun ditujukan untuk mengatur hal-hal yang khusus saja), bukan berarti ditafsirkan Perda yang mengatur soal BLUD itu dilarang. Raperda tentang BLUD tetap diperlukan, jika menurut hasil naskah akademik yang ada, itu sangat dibutuhkan oleh daerah. Bahkan substansinya dirancang lebih luas, ketimbang hal-hal yang cuma diperintahkan oleh Permendagri Nomor 61/2007 melalui peraturan kepala daerah dimaksud.

Alasan terakhir untuk menolak pemikiran sebagaimana tersebut di atas. Pertanyaan awal yang ingin diajukan, apakah Permendagri masuk dalam hierarki peraturan perundang-undangan? Tentu tidak. Lalu mengapa dijadikan landasan untuk menyatakan tidak dimungkinkannya sebuah Perda BLUD untuk dibuat? Andaikan juga

22 Lihat Sudikno Mertokusumo, "Penemuan Hukum”, Liberty: Yogyakarta, 2004, hal. 69-70 
Permendagri Nomor 61 Tahun 2007 menggunakan bahasa yang tegas, dengan menyatakan (misalnya): "BLUD tidak boleh dibuat dalam bentuk Perda, dan hanya dibuat dalam bentuk peraturan kepala daerah", maka jelas Permendagri ini dipandang cacat karena tidak memiliki kompetensi untuk mencantumkan materi muatan seperti itu. Bahkan bisa disebut, pihak yang mengeluarkan aturan hukum tersebut (dalam hal ini Menteri dalam Negeri, selaku pembantu presiden), telah melakukan anarkisme hukum dan melanggar asas ilmu perundang-undangan, di mana telah mengerangkeng atau menindas lembaga eksekutif maupun legislatif di tingkat daerah untuk memproduksi sebuah Perda, padahal aturan itu sangat dibutuhkan oleh daerah yang bersangkutan dan dijamin oleh konstitusi.

\section{KESIMPULAN}

BLU dapat dibentuk di semua lembaga dan instansi pemerintahan, baik pusat maupun di daerah. Di pemerintah pusat, BLU adalah instansi di lingkungan pemerintah yang dibentuk untuk memberikan pelayanan kepada masyarakat, berupa penyediaan barang dan/atau jasa yang dijual tanpa mengutamakan mencari keuntungan. BLU yang dibentuk di tingkat daerah (atau dikenal dengan singkatan BLUD), adalah SKPD atau Unit Kerja pada SKPD di lingkungan pemerintah daerah, di mana juga memiliki kesamaan fungsi dan tujuan dengan BLU yang ada di tingkat pusat.

Dalam melakukan kegiatannya, BLU dikelola secara otonom dengan prinsip efisiensi dan produktivitas ala korporasi. BLU bukan hanya terkait dengan visi, misi, dan program kerja secara umum. BLU juga terkait dengan keleluasaan dalam mengelola keuangan secara mandiri, sekaligus mencari pendapatan sendiri melalui pelayanan yang diberikan. Namun, untuk menunjukkan bahwa BLU merupakan bagian dari instansi pemerintah atau SKPD, maka dalam pengelolaan keuangan tersebut, tetap mendapat dana dari pemerintah, apakah itu melalui APBN atau APBD.

PP Nomor 23 Tahun 2005 tentang Pengelolaan Keuangan Badan Layanan Umum, mengatur lebih rinci mengenai BLU, yakni menyangkut tujuan, asas, persyaratan, penetapan, pencabutan, standar layanan, tarif layanan, pengelolaan keuangan, dan tata kelola BLU. Dengan melalui pola BLU dimaksud (sebagaimana juga diamanatkan oleh Penjelasan PP 23 Tahun 2005), diharapkan, tidak sekadar sebagai format baru dalam pengelolaan APBN atau APBD, tetapi BLU diharapkan dapat menyuburkan pewadahan baru bagi pembaharuan manajemen keuangan sektor publik, demi meningkatkan 
pelayanan pemerintah kepada masyarakat.

Sudah menjadi persepsi umum, bahwa pemerintah selama ini dinilai sebagai organisasi yang birokratis yang tidak efisien, lambat dan tidak efektif. Padahal dalam manajemen modern unit pemerintahan harus profesional akuntabel dan transparan. Lahirnya PP Nomor 23 Tahun 2005 tentang Pengelolaan Keuangan Badan Layanan Umum, dapatlah dipahami sebagai bentuk pengakuan secara tidak langsung atas persepsi masyarakat tersebut. Dengan kata lain, gagasan atas pembentukan BLU dimaksud, mengisyaratkan bahwa pemerintah sesungguhnya menyadari, mereka tidak dapat memberikan pelayanan secara maksimal kepada masyarakat secara terus menerus. Sekali lagi, lahirnya PP 23 Tahun 2005 tak ubahnya sebuah pengakuan yuridis dari pemerintah kepada masyarakatnya atas kelemahan dalam soal pelayanan dimaksud.

\section{Daftar Pustaka}

\section{Peraturan perundang-undangan}

Undang-Undang Nomor 1 Tahun 2004 tentang Perbendaharaan Negara

Peraturan Pemerintah Nomor 23 Tahun 2005 tentang Pengelolaan Keuangan Badan Layanan Umum

Peraturan Pemerintah Nomor 58 Tahun 2005 tentang Pengelolaan Keuangan Daerah

Peraturan Menteri Dalam Negeri Nomor 61 Tahun 2007, tentang Pedoman Teknis Pengelolaan Keuangan Badan Layanan Umum Daerah.

\section{Buku, jurnal, dan makalah}

Aditama, Tjandra, Manajemen Administrasi Rumah Sakit, Jakarta: UI Press 2007.

Afandi, Dedi, "Hak Atas Kesehatan adalah Hak Asasi Manusia", Makalah pada Seminar KOMNAS HAM-PWI Sumatera Selatan, Palembang, 16 Maret 2006.

Direktorat Pembinaan PK BLU Direktorat Jenderal Perbendaharaan Departemen Keuangan RI, Modul Bimbingan Teknis Penyusunan Persyaratan Adminstratif untuk Menerapkan PPK-BLU, 2008.

Djojosugito, A, Seluk Beluk Rumah Sakit Berbentuk Perusahaan Jawatan, Jurnal MARSI Vol. III, Nomor1, 2002.

Dwiyanto, Agus, dkk., Reformasi Tata Pemerintahan dan Otonomi Daerah, Yogayakarta: PSKK-UGM 2003. 
Islamy, M. Irfan, Reformasi Pelayanan Umum, Makalah Pelatihan Strategi Pembangunan Sumber Manusia Aparatur Pemerintah Daerah dalam Era Globalisasi, di Kabupaten Daerah Tingkat II Trenggalek, 1999.

Mertokusumo, Sudikno, “Penemuan Hukum”, Yogyakarta: Liberty 2004.

Moenir, H.A.S., Pendekatan Manusiawi Dan Organisasi Terhadap Pembinaan Kepegawaian, Jakarta: Gunung Agung 1998.

\section{Majalah, koran, dan situs web}

Ekonomi \& Bisnis Vol. 11, Nomor 2, Juni 2007.

Mahmudi, New Public Management (NPM): Pendekatan Baru Manajemen Sektor Publik, 2003. http://journal.vii.ac. id/index.php/ sinerji/artikel.

Media Tadulako, edisi VII, Juli 2012.

Republika, 18 Oktober 2005.

Supriyanto, Joko dan Suparjo, Disarikan dari Acara Workshop Penyusunan RPP tentang Pengelolaan Keuangan Badan Layanan Umum (BLU), 2010. www.perbendaharaan.go.id. 